\title{
Diaspora, cyberspace og etnicitet: Brugen af Internettet blandt yezidier
}

\author{
Af Andreas Ackermann
}

Hvori består et diaspora-fellesskab? Hvilken rolle spiller Internettet $i$ artikuleringen affallesskaber, det vare sig sociale og/eller virtuelle? Hvori består overhovedet yezidiernes fallesskab? Dette er nogle af de sporgsmål, den tyske kultur- og medieforsker Andreas Ackermann tager op $i$ denne artikel. Ackermanns arinde er flerfold. Han er forst og fremmest interesseret $i$ at undersoge, $i$ hoilket omfang yezidierne, som er en lille etnisk-religios gruppe af ca. 300.000 kurdisk talende mennesker, anvender Internettet som en »diasporiserings-teknologiu, dvs. til at styrke en falles gruppebevidsthed omkring et falles hjemland. I den sammenhang trakker Ackermann på nogle af de nyfortolkninger af diasporabegrebet, som er udviklet de senere år, men er samtidig hermed også ude $i$ et kritisk teoretisk arinde, nemlig at vurdere disse nyfortolkninger af diasporabegrebet. Den vesentligste "finding" $i$ den her fremlagte case er, at Internettet ikke forarrsager en diasporisk bevidsthed, men fremskynder sociale forandringsprocesser, der allerede er $i$ udvikling $i$ det virkelige liv.

Artiklen er oversat af Pernille Tufte

Denne artikel vil diskutere brugen af Internettet blandt de yezidiske kurdere ved at undersøge både institutionelle og personlige hjemmesider om yezidisme på World Wide Web. Artiklen vil fokusere på repræsentationen af yezidiernes kollektive identitet, i særdeleshed på hvilke aspekter der bliver fremhævet som afgørende elementer i yezidismen, og på hvilke måder betingelserne for diaspora bliver reflekteret på nettet. I tillæg til artiklens indhold vil links mellem forskellige yezidiske internetsider blive kortlagt med henblik på at analysere graden af sammenhæng mellem de forskellige repræsentationer. På baggrund af denne empiriske analyse vil sammenhængen mellem medier (i dette tilfælde Internettet) og etnicitet (her: diaspora) blive diskuteret.

Yezidierne, en lille etnisk-religiøs gruppe på ca. 300.000 kurdisk talende mennesker (fortrinsvis Kurmanji), udgør en minoritet i dobbelt betydning: for det første udgør de som kurdere en ofte forfulgt etnisk minoritet inden for grænserne af deres egne lande; for det andet er de som tilhængere af yezidismen en religiøs minoritet inden for den muslimske majoritet, hvor de ofte er blevet betegnet som »djævle-tilbedere«. Yezidierne har levet geografisk spredt i flere områder af Kurdistan (f.eks. Iran, Irak, Syrien og Tyrkiet) såvel som i Armenien og Georgien, hvor de fortrinsvis dyrkede korn og grøntsager og havde små besætninger af primært får og geder.

På grund af yezidiernes status som en undertrykt minoritet er det meget vanskeligt at fremskaffe pålidelige data om deres antal og aktuelle bopæl. Afhængig af, om kilden er yezidiske organisationer eller regeringer, varierer tallene betydeligt. De tal, der bliver brugt i det folgende, stammer fra Kreyenbroeks (1995) relativt konservative skøn. I dag bor de fleste yezidier (100.000-250.000) i Dohuk, Mosul og Sinjar områderne i det nordlige Irak, bosat i FNs såkaldte »safe-haven« nord for den 36. breddegrad. Ca. 5000 yezidier bor i Syrien, flest i området omkring Apello, mens mange af de ca. 10.000 yezidier fra Osttyrkiet er flyttet en masse til Europa i løbet af 1980'erne, primært til Tyskland, og urolighederne i det nordlige Irak har foranlediget, at mange prominente medlemmer af befolkningsgruppen dér er fulgt efter (Allison 1998, s. 14). Den senere nationalistiske udvikling i Armenien og Georgien har igen gjort situationen for de ca. 40.000 yezidier vanskelig. Som et resultat søger flere og flere asyl især i Tyskland. I øjeblikket formodes ca. 20.000 mennesker at bo i 
Tyskland - igen varierer tallene fra 10.000 (Kreyenbroek 1995, s. vi) til 30.000 (Dengê Êzîdiyan 1998).

Hvor yezidierne udgjorde nogle fintmaskede, klart afgrænsede samfund i deres respektive oprindelseslande, så har migrationsprocessen ændret referencepunkterne for den yezidiske identitet markant. Indtil for nylig har identifikationen som kurder, som medlem af lokalsamfundet, som medlem af en stamme og af en familie været defineret relativt klart. Og endnu vigtigere - at være yezidi har altid betydet, at man tilhørte en undertrykt minoritet, der var nødsaget til at skjule religiøse overbevisninger og adfærd. For eksempel blev »the institution of taquiya eller »vis forsigtighed «, som tillod én at skjule sin religiøse identitet i tilfælde af konstant fare for ens liv, traditionelt praktiseret af yezidierne (jf. Spuler-Stegemann 1997, s. 5). I nye omgivelser i eksil, under dramatisk ændrede livsbetingelser, får disse identifikationer gradvist mindre betydning. I Tyskland er yezidierne ikke længere forfulgt og behøver ikke at skjule deres religiøse overbevisning og adfærd - tværtimod er de nu nødt til at definere deres identitet gennem kulturelle og religiøse markører, som svarer til kravene fra et moderne, kulturelt komplekst samfund, der bevæger sig i retning af »multikulturalisme«. Derfor vil yezidierne skulle undergå en betydelig forvandling - fra religiøs usynlighed i de forskellige oprindelseslande til synlighed, hvad angår etno-religiøse markører i opholdelseslandet. Jeg vil beskrive denne forvandling som en »diasporiserings-proces« - som skabelsen af diaspora.

Et stort skridt i retning af skabelsen af en sådan yezidisk diaspora-identitet er forsøget på at sprede information om yezidisk kultur og religion blandt den bredere befolkning og blandt yezidierne selv. Flere kulturelle institutioner er blevet etableret i Tyskland med henblik på at forfølge dette mål. Blandt de mest betydningsfulde er $»$ Det kulturelle forum for den yezidisk religiøse befolkningsgruppe (Kulturforum der yezidischen Glaubensgemeinschafte.V). i Oldenburg og »Det udenlandske yezidiske center« (EziA) i Hannover. De forsøger at cirkulere information og stimulere diskussioner om yezidisme, fortrinsvis gennem publiceringen af deres respektive tidsskrifter $»$ Dengê Êzîdiyan«(»Yezidiernes stemme«) og »Roj«(»Sol«), et »tidsskrift om yezidiske anliggender«. Begge tidsskrifter bringer artikler - fortrinsvis på kur- disk og tysk, nogle gange på engelsk, tyrkisk og arabisk - om yezidiernes historie, om religiøse tekster og adfærd samt rapporteringer om situationen i de yezidiske samfund i de respektive oprindelseslande og i Tyskland, hvilket allerede af og til bliver refereret til som »diaspora«.

Selvom begrebet »diaspora« efterhånden er blevet en metaforisk betegnelse til at beskrive forskellige kategorier af mennesker såvel som forskellige befolkningsgrupper, hvis fællesnævner mere eller mindre er følelsen af »ikke at være der« (Safran 1991, 83), forekommer brugen af begrebet nyttigt og passende i yezidiernes tilfælde, omend der er tale om »en begyndende diaspora«. Oprindeligt for jøderne var diaspora et udtryk for et kollektivt traume, en forvisning, hvor man drømte om hjem, men boede i eksil. Andre befolkningsgrupper, bosat i udlandet, der også har bevaret stærke kollektive identiteter, har i de senere år defineret sig selv som diasporaer, selvom de hverken var aktive repræsentanter for kolonisering eller passive ofre for forfølgelse. Da selve ideen med en diaspora varierer meget, har især Safran (1991) og Cohen (1997) forsøgt at finde nogle fælles træk i de forskellige forslag til karakterisering af en diasporabefolkningsgruppe. Ved at sammenstille dem kan man destillere en arbejdsdefinition, som er baseret på tre primære kendetegn: 1) en - oftest traumatisk - spredning fra et oprindelsesland eller »centrum « til to eller flere udenlandske eller »perifere« regioner; alternativt en udvidelse af hjemlandet i søgen efter arbejde eller i handelsøjemed; 2) en stærk (etnisk) gruppebevidsthed i forening med en kollektiv hukommelse og myte omkring hjemlandet og ønsket om en eventuel tilbagevenden; og 3) indlevelse og sympati med andre etniske medlemmer, bosat i andre lande. I forlængelse heraf udgør yezidierne endnu ikke en diaspora, simpelthen fordi det ikke står klart - ikke engang for yezidierne selv - i hvilke andre europæiske lande de yezidiske migranter bor, bortset fra befolkningsgrupperne i Irak, Syrien, Armenien og Georgien (med hvem det er meget vanskeligt at fastholde kontakten).

Hvad der imidlertid gør Cohens begrebsliggørelse af diaspora specielt interessant i denne aktuelle kontekst, er hans forsøg på at fjerne sig fra den entydigt negative betydning af begrebet. Til sin omfattende liste af diaspora-kendetegn føjer han muligheden for et særligt kreativt og berigende diasporisk liv i værtslandene med en tolerance 
overfor pluralisme (Cohen 1997, s. 21). Overfor »Babylon-perspektivet«, som udelukkende forbinder den jødiske diaspora med slaveri, eksil og tvangsforflyttelse, præsenterer Cohen det »revisionistiske syn«, der understreger fordelene ved integration i en rig og anderledes udenlandsk kultur. Ifølge ham overtog et væsentligt antal af judæanere babylonske navne og skikke; gruppen som helhed brugte den babylonske kalender og tog fat på det amaraiske sprog. Deres påtvungne bosættelse i Babylon gav dem mulighed for at skabe og definere deres historiske erfaring, at »opfinde« deres traditioner. Myter, folkesagn, mundtlige overleveringer og juridiske dokumenter blev samlet $\mathrm{i}$ en spirende bibel, mens diskussionsgrupper samledes hos karismatiske figurer som Jeremiah og Ezekiels i deres hjem, der siden blev forvandlet til begyndende synagoger (Cohen 1997, s. 4).

Forståelsen af diaspora - ikke kun som en oplevelse af eksil og tvangsforflyttelse, men også som et potentielt kreativt miljø - synes oplagt til at beskrive og analysere det yezidiske samfund i Tyskland. Som medlemmer af dette samfund ser det:

I Tyskland har yezidierne en historisk chance, nemlig frit at kunne udtrykke deres tanker og følelser på skrift og friheden til at kunne udgive disse. Udviklingen af en yezidisk litteratur er et fundamentalt behov for den yezidiske identitet $\mathrm{i}$ dette moderne samfund.

I denne sammenhæng har diaspora'er uforholdsmæssigt store fordele af de mange forandringer i teknologi, økonomisk organisering, rejseformer, produktion og kommunikation, der har fået betegnelsen »globalisering«. I det omfang, hvor rejser såvel som kommunikation over lange afstande bliver nemmere og billigere, har flere og flere diaspora-medlemmer råd til at fastholde en regelmæssig kontakt. Udover telekommunikation og videoteknologi er det særligt Internettet, der får stadig større betydning. Da det økonomisk er relativt overkommeligt og derfor tilgængeligt for et stort antal brugere, da det er relativt svært for de statslige autoriteter at kontrollere, og samtidig i stand til at transportere store mængder af tekst, billeder og lyd over hele verden uden hensyn til nationale grænser, udgør det en kæmpe »diasporiseringsteknologi« (Tölöyan). I det følgende vil jeg se på, hvordan Internettet bliver brugt som en sådan diasporiserings-teknologi af yezidiske organisationer og enkeltpersoner.

\section{Yezidiske identitetsmakører}

Når man taler om identitet, bliver begrebet på et generelt niveau forstået som et udtryk for en sammenhæng i grupper, som er socialt konstruerede fremfor kulturelt »givne«. Medlemmerne af en gruppe understreger deres »ensartethed « ved at identificere sig selv med karakteristiske kvaliteter, der kan relateres til sprog, den materielle kultur, religion, slægtskab, men også køns-, aldersog professionsspecifikke karakteristika (jf. Müller 1987). Begrebet gruppe betyder, at medlemmerne har noget tilfælles med hinanden, som adskiller dem markant fra medlemmer af andre formodede grupper. Gruppeidentitet refererer derfor samtidig til både lighed og forskellighed. Ordet har således en relationel betydning: en gruppes modsætning til andre grupper eller andre sociale enheder. Fordi brugen af ordet "gruppe« udtrykker en afstand, synes det passende at fokusere på grænser snarere end på de kulturelle traditioner, som grænserne antagelig sikrer (jf. Barth 1969).

Betegnelsen »yezidi« synes at stamme fra det persisk-kurdiske ord »Azdan«, der betyder »Gud« (Dulz 2000, 3). Yezidierne ser sig selv som et udvalgt folk, hovedsagligt fordi deres oprindelse er meget speciel ulig mange andre folkeslag. De er efterkommere af Adams søn Shehîd b. Jerr (»Vidne, Jars søn«):

Ifølge overleveringen hævdede Adam, som var irriteret over Evas påstand om, at alle deres børn tilhørte hende, at det var faderen, der giver liv til hans afkom. For at bevise dette udfordrede han Eva i en konkurrence. Begge opbevarede deres frø i forskellige krukker. Efter ni måneder indeholdt Evas krukke kun orme og insekter, men Adams frembragte Shehîd. Sidstnævnte giftede sig efterfølgende med en huri fra Paradis, og yezidierne er efterkommere af denne forening (Kreyenbroek 1995, 37).

Yezidismen, som man kender den i dag, er en videreførelse af en bevægelse, der stod for en mytisk fortolkning af Islam ved »Adawiyya ordenens Sheykh »Adi ibn Musafir«« (c.1073-1162 AD), der indsatte sig selv i Kurdistan. Hans helligdom i Lalish, nær Dohuk (det nordlige Irak) udgør det vigtigste religiøse sted for yezidierne, og det er hvert efterår målet for de troendes årlige pilgrimsfærd. Yezidiske tekster og skikke viser imidlertid, at Sheykh 'Adi og hans ordens enorme indflydelse 
byggede på endnu ældre overbevisninger, fordi væsentlige dele af den yezidiske mytologi og adfærd har gamle iranske rødder. Der er ligheder mellem yezidiernes religion og andre gruppers religion, der påberåber sig islamisk identitet, som fx Alevi'erne og Ahl-e Haqq fra det iranske Kurdistan.

Det er vigtigt at bemærke, at yezidismen ikke er en bibelsk religion, da dens hellige tekster er blevet overført mundtligt gennem generationer, og det at kunne læse og skrive tidligere var forbudt for yezidierne. Allison har således beskrevet det som en religion of orthopraxy, snarere end en ortodoks religion, da den ikke har en enkelt troserklæring, der kan favne alle yezidier, eller en enkelt måde at bede på (Allison 1998, 14). På den måde er det et trossystem i meget løs forstand med mange variationer i praksis. Overordnet set er der syv hellige guder, der bliver holdt i ære, fortrinsvis Melek Tawus, Påfugle-englen (der af flere ikke-yezidier bliver identificeret som Satan). Disse kan blive legemliggjort i menneskelige skikkelser op til flere gange og bliver kaldt khas. Denne institution gør det muligt for yezidierne at indlemme hellige figurer fra andre religioner. Der er således islamiske figurer som Ali, kaliffen Abu Bakir og hasan alBasri, der bliver holdt i ære, og fra kristendommen bliver Jesus sat lig med den yezidiske Sheykh Shems. Vigtigheden i at respektere renhed ligger åbentlyst ikke kun i yezidiernes opfattelse af elementerne, primært jord og ild, men er også til stede i det kastesystem, som er et særligt træk ved det yezidiske fællesskab.

Yezidierne er opdelt i to grundlæggende klasser eller kaster, lægmændene eller de borgerlige kaldet mirîd, og de gejstlige kaster. Ordet mirîd, et oprindeligt Sufi-udtryk, er betegnelsen for Herrens »disciple«. Generelt bliver ordet dog brugt til at betegne dem, der ikke tilhører de gejstlige (Kreyenbroek 1995, 135). Gruppen bliver ledet af Mîren af Sheykhan, der traditionelt er blevet anset for at være Sheykh 'Adis (og også Melek Tawus') viceregent, og af Baba Sheykh (»Fader Sheykh«), lederen af Sheykh'erne og således den åndelige trosleder. Mens Mîrens magt teoretisk er stort set ubegrænset - han kan ikke blive afsat og har ret til at bandlyse enhver troende efter behag - så har dødbringende skænderier og barske politiske realiteter haft den effekt, at hans autoritet er blevet delvist forringet.

Gejstligheden er igen opdelt i flere kaster eller titler, blandt hvilke Sheykhen og Pîren er de vigtig- ste. Enhver yezidi - også Sheykhen og Pîren selv - skal have en Sheykh og en Pîr. Således har hver enkelt Sheykh et antal lægmandsfamilier, som er hans mirîd eller »tilhængere«. Han fungerer som deres åndelige vejleder ved at samle til bønner eller gennemtvinge tabuer, og forventes at deltage på deres vegne i gennemførelsen af religiøse ceremonier som f.eks. fødsel, ægteskab eller død. Til gengæld betaler mirîd'en Sheykhen og Pîren en given sum penge hvert år, de viser ham stor respekt, og i et vist omfang adlyder de hans autoritet.

En anden afgørende faktor i yezidiernes særlige karakter er deres strenge regler vedrørende giftermål inden for kasten. Enhver yezidi skal finde sig en passende partner inden for sin egen kaste, hvorved Sheykherne og Pîrerne ofte skal tage hensyn til endnu vanskeligere regler, hvad angår bestemte familier. Hvis en yezidi gifter sig med en ikke-yezidi, vil han eller hun ikke længere blive betragtet som medlem af fællesskabet. Man kan altså ikke konvertere til yezidismen, man kan kun blive født som en yezidi. Deres opfattelse af sig selv som et udvalgt folk med strenge regler for ægteskab og forbuddet mod konvertering bidrager yderligere til at isolere befolkningsgruppen og medvirker til at støde de yngre yezidier, der er opvokset i Tyskland, bort. Reglerne for giftermål inden for kasten er yderligere medvirkende til, at nogle personer (specielt fra de gejstlige kaster) ikke kan finde en passende partner at gifte sig med i Tyskland. Derfor er unge yezidier begyndt at gøre oprør imod sådanne fundamentale regler som at gifte sig inden for kasten. Derfor er det ikke overraskende, at eksil-yezidiernes situation er blevet sammenlignet med en sukkerknald i varmt vand.

Som yezidierne bliver mere urbane og lærer at læse og skrive, begynder de unge medlemmer af fællesskabet at udtrykke behov for et religiøst koncept med kerneoverbevisninger, der kan diskuteres intellektuelt indenfor fællesskabet og samtidig forklares til udenforstående. Forskellig fra traditionen, hvor kun Sheykherne og Pîrerne kunne debattere religiøse temaer, bør yezidierne i Tyskland kunne forklare deres religiøse begreber offentligt, f.eks. i retten, når de ansøger om asyl. I et betydeligt antal sager er yezidier blevet nægtet asyl, netop fordi de ikke var i stand til det (jf. Kulturforum der Yezidischen Glaubensgemeinschaft 2000). De fleste mirîd'er ved stort set ingenting om deres religion, bortset fra de mest basale ting om Melek Tawus og nogle religiøse restriktioner, specielt 
vedrørende mad. De var indtil for nyligt analfabeter og var derfor totalt afhængige af de gejstlige kaster til at informere dem om deres religion. Yderligere, på grund af deres geografisk spredte bosættelser, kunne det ske, at de kun fik besøg af deres Sheykher og Pîrer en enkelt gang om året, og ofte blev der lokalt udviklet forskellige traditioner. Derfor ved de fleste mirî̀'er kun ganske lidt om deres religion, og deres børn endnu mindre.

De ældste yezidier har indset, at deres fællesskabs fremtid i Europa er på spil, og de har derfor taget initiativ til at indsamle alle mundtlige overleveringer og skabe den hellige skrift og samtidig reformere nogle af tabuerne. Set i lyset af den udbredte frygt for, at den yezidiske identitet vil kunne forsvinde som følge af migration, blev en seks-punkts deklaration under et besøg i Tyskland i 1997 godkendt af Civata Ruhani, yezidiernes religiøse råd, der omfatter Mîrerne og Baba Sheykh såvel som flere feqir'er (yezidiernes religiøse orden) og quewwal'er (som spiller hellig musik under religiøse ceremonier). Deklarationen kræver, at alle relevante mundtlige overleveringer bliver indsamlet, at den hellige skrift bliver skabt, og at nogle af tabuerne bliver reformeret. Med hensyn til det sidstnævnte aspekt står der i teksten:

Vi er nødt til at konkurrere med andre livssyn og andre værdisæt. Visse traditioner og skikke, der ikke længere er aktuelle og ikke er relateret til vor religions kernesager, skal reformeres eller helt opgives. Ellers vil ungdommen fjerne sig fra både os og fra yezidismen, som det allerede ses i Tyskland (Dengê Êzîdiyan 6/7 1997, 60; min oversættelse).

Migrationsprocessen synes således at forårsage en dobbeltsidet forvandling af det yezidiske fællesskab: på den ene side vil »yezidismen ændre sig fra at være en mundtlig (orthopraxy) religion til at være en skriftlig ortodoks religion« (Allison 1998, 14), hvorved der sker en homogenisering af den yezidiske identitet i diasporiseringsprocessen. På den anden side vil også den sociale struktur i det yezidiske fællesskab ændre sig, især med hensyn til opdelingen mellem mirîd og gejstligheden, hvis autoritet der i stadig stigende grad bliver stillet spørgsmål ved i det moderne samfund.

\section{Yezidisme på web'en}

I betragtning af, at den yezidiske befolkningsgruppe i Tyskland er relativt lille, er den godt beskrevet på nettet. Ved at se bort fra websites med grundlæggende information om yezidierne (fx opslagsord i encyklopædier eller sider fra humanitære organisationer) og i stedet fokusere på dem, der er lavet af yezidierne selv, finder man a) to institutionelle sider, der beskriver Oldenburgs kulturelle forum og Det udenlandske yezidicenter; b) to personlige hjemmesider af Arture Razgoev og Mirza Dinnayi; og c) et diskussionsforum, igen fra Oldenburgs kulturelle forum. Et website, der bliver lavet af Onnik Krikorian, formodentlig en ikkeyezidisk, armensk journalist med base i Yerevan, vil også blive inddraget $i$ analysen, fordi den giver en stor mængde information om yezidierne i Armenien. Med undtagelse af de to sider af Razgoev og Krikorian - som begge har base i USA er alle servere placeret i Tyskland. Et kig på disse sider vil kunne medvirke til at danne grundlaget for en mere oplyst diskussion om Internettets rolle i repræsentationen af etniske/diasporiske fællesskaber.

\section{a) Institutionelle websites}

»Det yezidiske Forum« er blevet dannet af Oldenburgs kulturelle Forum og har et relativt professionelt design, skabt af en marketingsvirksomhed. Den første side gør det muligt for den besøgende at vælge mellem engelsk, kurdisk og tysk som sproget for visningen af siderne, symboliseret ved det engelske, kurdiske og tyske nationalflag. Når man har foretaget sit valg, bliver den besøgende budt velkommen af Melek Tawus' symbol, påfugle-englen. Og den besøgende bliver informeret om, at

formålet med Dengê Êzîdiyans hjemmeside er at sprede og udveksle information og dermed oplyse om yezidiernes kun sjældent undersøgte og ofte misforståede kurdiske religion - yezidierne, der bor i Irak, Armenien, Georgien, Tyrkiet og Syrien, og diasporaen i Tyskland.

Web-siden har en vertikalt opsat menu i venstre side, som gør det muligt for læseren at vælge mellem flere muligheder, afhængig af det givne sprog. En kort introduktion (»Vi præsenterer os selv«) fortæller læseren, at 
yezidierne har behov for et forum for diskussion og refleksion over deres liv og problemer inden for en kontekst af de yezidi-religiøse lærdomme. (...) DÊ henvender sig ikke kun til yezidier, men hovedsagligt til dem, der er interesserede i at udvide deres religiøse og kulturelle viden. Formålet med DÊ er: en efterfølgende kontroversiel debat. Denne intensive diskussion om yezidisme, der var så kortfattet i den yezidiske historie, er en mosaiksten i det udtømmende enhedsbillede i yezidi-tapetet.

Det næste punkt i menuen lover svar på spørgsmålet: »Hvem er yezidierne?«. Den respektive side er illustreret med to billeder af Lalish, yezidismens religiøse centrum, og Baba Sheykh, fællesskabets åndelige leder. Den informerer den besøgende om, at de monoteistiske yezidier er en gammel kurdisk religiøs minoritet, og at yezidisme menes at være den »originale« religion for alle kurdere, selvom islamiseringen skulle have reduceret yezidiernes antal til 800.000. Endvidere bliver det yezidiske fællesskabs problemer med dets manglende tradition for ortodoksi pointeret:

Op gennem historien var religiøs forfølgelse hovedårsagen til, at det ikke var muligt for yezidierne at udvikle deres egen litteratur. Derfor var det ekstremt svært for den yezidiske religion og kultur at udvikle sig yderligere. Den mest alvorlige konsekvens af dette er, at der ikke eksisterer en enkelt yezidisk teologi.

Ved at ignorere det seneste dobbelt-nummer af tidsskriftet samt link'et til diskussionsforummet (som vi vil besøge senere) og søgefunktionen, er det muligt at browse gennem en rapport om menneskerettighedssituationen hos den yezidiske befolkningsgruppe i Georgien (kun i Tyskland). Den tysk-sprogede version tilbyder i tillæg de seneste »nyheder« (dog er de seneste fra 1997) vedrørende yezidiske anliggender, f.eks. om valget af en ny religiøs leder (»Baba Sheykh«) i det nordlige Irak, om et projekt omhandlende et nyt kulturelt center (som er åbnet i mellemtiden), om dannelsen af et yezidisk fodboldhold, osv.

Web-siden er grundlæggende designet som en online-version af Kulturforummets tidsskrift »Dengê Êzîdiyan«: afhængig af det valgte sprog, finder man mange eller kun få udvalgte artikler fra de forskellige numre. Blandt emnerne er: »Religion«, »Samfund«, »Historie«, »Kurdistan« og
»Kultur«. De udgør ialt 32 artikler på tysk, 26 artikler på kurdisk og 7 artikler på engelsk. Naturligvis er der også de sædvanlige »links til yderligere information « - i dette tilfælde dog begrænset til hhv. kun en eller to, afhængig af det valgte sprog: den engelske version link'er læseren til »De truede folks samfund « (»Gesellschaft für bedrohte Völker«, Gfb V), en tysk NGO, den tyske version tilbyder også en link til en tysk jødisk hjemmeside, der hedder »haGalil onLine«. Den kurdisksprogede side tilbyder slet ingen links. Generelt er meningen med denne side ikke at give »de seneste nyheder « om den yezidiske befolkningsgruppe i Tyskland (den blev »sidst ændret« i juli 1998 og har ingen tæller), men snarere at give en grundig information om yezidisk religion og kultur til et bredere publikum end kun yezidierne selv.

»Yezidi Web« er Det udenlandske yezidicenters website, lavet og vedligeholdt af Mirza Dinnayi, en yezidier der oprindeligt kommer fra Irak. Siden blev sidst ændret i februar 2000 og er ifølge tælleren blevet besøgt 8847 gange frem til den 4. august 2000. Indgangssiden har en horisontal menu, hvor man kan vælge mellem tysk, arabisk, kurdisk og engelsk som sproget for visningen af siderne. Den vertikale menu til venstre præsenterer forskellige links. I modsætning til »Det yezidiske Forum « er mulighederne de samme indenfor hvert sprog, selvom den besøgende snart vil finde ud af, at mange af de forskellige links ikke fører nogen steder hen - »denne side er under opbygning«. Indtil videre er mulighederne på arabisk og kurdisk bogstaveligt talt virtuelle, da de fleste sider er på engelsk eller tysk (hvor niveauet langt fra er perfekt). Herudover byder portalen på en banner, der informerer om den »Første verdenskongres om yezidisme«, den viser et billede af en karakteristisk tempel-kuppel fra Lalish og en formålserklæring. Den besøgende bliver fortalt, at denne side

har til formål (sic) at formidle, indsamle og diskutere alle videnskabelige informationer om denne religion, at hjælpe læserne til at møde (=finde) de korrekte informationer (om) os.

Den første link på menuen giver den besøgende mulighed for se på udvalgte dele af EziAs tidsskrift »Roj«, men ikke for at bringe nogle artikler frem. Den næste valgmulighed bringer os til »Det internationale informationscenter for yezidiologi som dog stadig er i projektfasen. Ifølge meddelel- 
sen er formålet med centeret at indsamle og udgive al tilgængelig information om yezidierne, såvel i litteraturen som på WWW, for at bidrage til en mere generel diskussion om yezidisme med yezidier og videnskabsmænd i religion. Det næste klik er et link til »Det udenlandske yezidicenter« (EziA), som er

en kulturel og social organisation, der beskæftiger sig med forhold, der vedrører den yezidiske religion i eksil. En af de vigtigste opgaver for denne organisation er at publicere denne religions ideer. EZiA repræsenterer yezidier i udlandet. Et andet mål med denne organisation er at samarbejde med videnskabsfolk og eksperter i den yezidiske religion om at indsamle, undersøge og publicere vores religion, som er en af de ældste religioner i verden. I tillæg til vores kulturelle og sociale aktiviteter arrangerer EZiA sammen med dens afdelinger over hele verden yezidiske kulturelle og religiøse festivaler.

Mens »Dit spørgsmål« tilbyder den besøgende at sende et spørgsmål via e-mail til redaktøren, bekendtgør »Om os« EZiAs intentioner (kun i Tyskland) om at distribuere informationer om yezidisme på Internettet. EZiA påstår at repræsentere yezidierne i udlandet og tilbyder at samarbejde med religiøse videnskabsmænd $\mathrm{i}$ indsamlingen af den yezidiske historie, hvis rødder stadig står overfor at blive afsløret. Linken til »Billeder fra den yezidiske kultur« er - igen - »under opbygning «, men man kan bestille adskillige artikler om yezidisme i »boghandlen«. Listen gør det muligt for læseren at vælge flere numre af »Roj«, en »Tilgang...." af Khalil Rashow (medlem af EZiA), arabiske digte af Mirza Dinnayi, en artikel om »Yezidiernes position og de fremtidige perspektiver for integration i det tyske multikulturelle samfund« (på tysk), igen af Dinnayi, en kurdisk novelle af Amer Celik, og endelig dokumenterne fra den »Første verdenskongres om yezidisme« (som dog stadig står overfor at blive publiceret).

Den yezidiske web har også en gæstebog, men med kun 12 besøg frem til i dag (04.08.00), hvoraf de fleste er opmuntrings-tilkendegivelser. Selvfølgelig er der også en søgefunktion og andre links relateret til yezidiske anliggender. De leder den besøgende til Instituttet for iranske studier på Göttingens Universitet (hvor et medlem af EZiA, Khalil Rashow, er lektor i kurdisk sprog), til Mirza Dinnayis hjemmeside (se næste afsnit), Dengê
Êzîdiyan internationale online-diskussionsforum (som vi også vil besøge senere), og endelig det allerede omtalte »De truede folks samfund (som hjalp i organiseringen af den »Første verdenskongres om yezidisme«).

\section{b) Personlige websites}

Som »Yezidi Web« er Mirza Dinnayis personlige website mere eller mindre »under udvikling «. Den er sidst blevet ændret den 15. april 2000, og tælleren viser 1139 besøgende pr. 4. august 2000. I øjeblikket tilbyder siden kun et link til hans elektroniske spørgeskema vedrørende de migrationsspecifikke aspekter ved sundhedsproblemer, som han har til hensigt at bruge i sin afhandling i medicin. Bortset fra det bliver læseren opfordret til at »læse noget af mit arbejde«, som indbefatter de før omtalte digte på arabisk (vist som hemmelige symboler, der ikke kan tydes), en tysk og en kurdisk version af hans allerede nævnte artikel om de fremtidige perspektiver for yezidierne i det multikulturelle Tyskland (hvoraf ingen af dem kan drages frem), og endelig hans arbejde, der er blevet publiceret i Roj. Igen er det et »dødt« link.

Razgoev Arture Felix's personlige hjemmeside er skrevet på engelsk og er den mest farverige og mindst strukturerede af dem alle. Ifølge en e-mail, som han skrev til Dengê Êzîdiyans diskussionsforum, er han 17 år gammel, af »yezidisk nationalitet« og bor i Toronto, Canada. Hans side er dedikeret til hans bedstefar Razgoev Bajloze Chachan. På siden er vist et fotografi af sidstnævnte i militæruniform, et kort over Kurdistan (»Kurdernes og yezidiernes land «), det kurdiske flag, Melek Tawus symbolet fra Dengê Êzîdiyan-hjemmesiden, to billeder af »den største kurdiske sanger Sivane Perwar«, et billede af en folklore-gruppe, og to billeder af det kurdiske landsskab. En kort introduktion til yezidierne (som åbenlyst er kopieret fra Det yezidiske forum's side) siger, at

De monoteistiske yezidier er medlemmer af en gammel (sic) religiøs kurdisk minoritet, hvis rødder går tilbage til 2000 f.kr., til den Mithraistiske tid. Det var tilsyneladende kurdernes originale religion. Via den obligatoriske islamisering blev yezidiernes antal reduceret (sic) til de nuværende 800.000 .

Alt dette er indrammet af tapetlignende ornamenter, fyrværkeri og en e-mail-knap. Siden tilbyder 
tre links, til den nævnte Sivane Perwar, til fotoalbummet og til kurdenes historie. Mens linken til »den største kurdiske sanger« fører til en kurdisksproget online musik- og boghandel i Sverige, viser fotoalbummet - denne gang indrammet af blå vindruer - endnu engang billedet af hans bedstefar samt et billede af Artures familie i den »yezidiske landsby Alagiaz« (Armenien). Et billede af Arture viser ham under overskriften på »Velkommen til min yezidier-side (sic) « med armene over kors foran et kæmpe vandværk med gyldne statuer. Endelig er der et billede af bedstefaderens gravsten, også i Alagiaz. Bortset fra dette får vi ingenting at vide om Arture eller hans bedstefar. Yezidierne bliver heller ikke nævnt. Denne side tilbyder flere links, igen til online musik- og boghandlen, til Dengê Êzîdiyan (»endnu en side om yezidierne«), og to artikler om »Kurderne og islam« og $»$ Kurderne i dag og i morgen «, begge publiceret af et »Internationalt tyrkisk netværk«(som »fortæller om Guds bedrifter og bygger broer for Kristus i Tyrkiet«). »Razgoevs Kurdernes historie« spænder over en periode fra omkring 12.000 år tilbage og frem til 1990'erne og siger, at

Kurderne og deres historie er det endelige resultat af tusinder af års fortsatte indre udvikling og nye folk og ideers assimilation, sporadisk introduceret i deres land.

Igen er der ingen yderligere oplysninger om yezidierne i Armenien eller andre steder.

\section{- Onnik Krikorian}

Onnik Krikorian, en armensk foto-journalist med base i Yerevan (den armenske republik), har en side, der er fremragende på to måder - den er den mest sofistikerede, hvad angår design, og den fokuserer specifikt på politikken vedrørende den yezidiske identitet i Armenien. Den hører til hos det USA-baserede »Freespeech Internet Television« og giver en masse baggrundsinformation om den politiske situation blandt de armenske yezidier. Med et fotografi som baggrund, der viser en pige foran et billede af »en PKK-martyr«, giver Krikorian et kort resume af den nuværende situation i Armenien, hvad angår den kurdiske befolkningsgruppe som helhed og den yezidiske gruppe i særdeleshed. Ifølge ham er de armenske yezidier delt i to grupper - de, der betragter sig selv som kurdere, og de, der betragter sig selv som yezidier som en separat etnisk identitet. Denne op- deling kan overdrives yderligere ved indblanding af udefrakommende styrker som f.eks. Det kurdiske Arbejderparti (PKK) og andre nationalistiske styrker indenfor republikken. Krikorians sider fokuserer på denne splittelse og de komplikationer, den kan skabe for den yezidiske befolkningsgruppe. Krikorian afslører ikke, om han opfatter sig selv som yezidi - faktisk giver han ingen indikationer vedrørende sin egen tilknytning.

Fire links bliver anført - den ene leder til et kort over Armenien med den grundlæggende information om landet, den næste leder til mere end 20 fotos af (yezidiske) kurdere i Armenien. Den tredje knap på menuen leder til ca. 10 artikler og interview af Krikorian, enten med yezidiske repræsentanter eller politikere, der arbejder med yezidiske anliggender. Den sidste knap tilbyder den lejlighedsvise »www links«, denne gang til Dengê Ézîdiyan, »Groong Armenian News Network« og "Aragil News«, et dagligt sammendrag fra armenske aviser på engelsk. Der er ingen tæller eller dato for sidste ændring.

\section{c) Dengê Êzîdiyans internationale diskussionsforum}

Langt det mest dynamiske område i den yezidiske del af cyberspace - hvad angår spørgsmålet om den kollektive identitet-er Dengê Êzîdiyans e-mail diskussionsforum, hvor mange forskellige emner bliver diskuteret mellem yezidier, muslimske kurdere, tyskere og andre ikke-yezidiske besøgende, ofte på en polemisk og ophedet måde. Fra den 7. maj 1998 til den 6. august 2000 har der været 414 bidrag, hovedparten (265) på engelsk, efterfulgt af tysk (121), kurdisk (21) og tyrkisk (8). Når man ser på indholdet $\mathrm{i}$ indlæggene og husker på, hvad der blev nævnt indledningsvis om den manglende viden både blandt mirid'erne og ikke-yezidierne, er det ikke nogen overraskelse, at det meste af debatten og de fleste kommentarer vedrører emnet religion og kulturelle traditioner (233). For det meste angår de generel information om yezidierne, f.eks. hvem der bliver deres politiske/spirituelle leder, hvorvidt yezidismen kender til religiøse bøger, hvilke religiøse madrestriktioner der findes, etc. (108). Herefter kommer det essentielle spørgsmål om, hvorvidt yezidierne »virkelig« er Zoroastrianere (52). Selvom der har været flere forsøg på at besvare dette spørgsmål, hvoraf de fleste argumenterer imod denne opfattelse (f.eks. Kreyenbroek 1995, 60f.), har de ikke kunnet sætte en 
stopper for diskussionen. Reformen af kulturelle og religiøse traditioner - som antagelig er nødvendig, hvis yezidismen skal have en fremtid i diasporaen - bliver på samme måde debatteret i cyperspace (47). Det inkluderer spørgsmålene om medgift, arrangerede ægteskaber og forbuddet mod ægteskab med ikke-yezidier, hvilket synes at være en endeløs kilde til bitre opgør blandt yezidier fra forskellige generationer (18), såvel som kvindernes rolle i det yezidiske samfund (5).

Det næste væsentlige emne er omstændighederne omkring forfølgelse, flugt og de administrative procedurer, som migranter/flygtninge møder i løbet af deres rejse og på deres nye bopæl (66). Spørgsmål om den aktuelle politiske status blandt yezidierne i oprindelseslandet dukker ofte op. Af og til spørger medlemmer af NGO'er og menneskeretsorganisationer, der tager vare på yezidiske asylansøgere, efter landespecifik information vedrørende deres respektive status. Et andet vigtigt tema for diskussion er forholdet mellem yezidier og kurdere (36), som har vidtrækkende betydning for befolkningsgruppens identitetsopfattelse. Det er formodentligt sikkert at sige, at hovedparten af yezidierne betragter sig selv som kurdere og er blevet vant til ideen om, at alle kurdere oprindeligt var yezidier, før de tvungent konverterede til islam. I tillæg hertil har problemet et politisk aspekt, hvor yezidierne må placere sig selv i den kurdiske politik. Selvom de fleste yezidier sandsynligvis deler utopien om et »Frit Kurdistan«, er spørgsmålet om politisk tilknytning til enten Det kurdiske Arbejderparti (PKK) i Tyrkiet og Tyskland eller Det kurdiske demokratiske Parti (DPK) og Den kurdiske patriotiske Union (PUK) i Irak, langt mere vanskeligt at besvare og af og til forbundet med alvorlige konsekvenser.

Overraskende nok er forholdet mellem yezidier og tyskere stort set ikke et tema for diskussion, og derfor er der næsten ingen omtale af forholdet til det faktiske miljø i det diasporiske yezidiske fællesskab. Kun 12 ud af 414 meddelelser berører emnet og det på en ganske særlig måde. De er blevet udløst af en tysk pige, der blev forelsket i en yezidisk dreng, hvis forældre gjorde en ende på forholdet. Hendes bitre mellemværende startede en kortlivet række af bidrag, der diskuterede forklaringer på de yezidiske traditioner og deres legitimitet i det tyske samfund.

Dette fører os til den mere abstrakte diskussion af indholdet af den yezidiske tilstedeværelse på In- ternettet, særligt med hensyn til spørgsmålet om i hvilket omfang yezidierne bliver betragtet som et diasporisk fællesskab. Ved et gennemsyn af de forskellige websites vedrørende deres beskrivelse af yezidisme kommer man til den konklusion, at - til trods for deres formodede kurdiske kulturelle baggrund - er de afgørende markører i den yezidiske identitet skabt af deres religiøse traditioner. Derfor understreger Det yezidiske Forum såvel som Den yezidiske Web (samt Arture Razgoev, som mere eller mindre kopierer information fra Det yezidiske Forum) det religiøse aspekt ved yezidismen, som man går ud fra enten er »erindringen om den ældste religion i Mesopotamien« (Den yezidiske Web) eller endda »en af de ældste religioner i verden« (Det yezidiske Forum). De forskellige websites er dekoreret med billeder af påfuglen Melek Tawus, af Baba Sheikh og helligdommen i Lalish og afbilleder derved den religiøse kerne ved den yezidiske identitet. Ifølge Tolan, redaktør af Det yezidiske Forum

... er der ingen tvivl om, at yezidierne er kurdere. Yezidisme er ikke en etnisk, men en religiøs afgrænsning. Yezidier er kurdere. De taler kurdisk, og deres bønner og religiøse tekster er holdt på kurdisk. Man kan sige, at de yezidiske kurdere fastholder den oprindelige kurdiske kultur i modsætning til de muhamedanske kurdere, der har tilpasset deres religion den arabiske kultur!

Det er kun Krikorian, der påpeger det faktum, at i Armenien er yezidierne opdelt i to grupper - de yezidier, der opfatter sig selv som kurdere, og de, der opfatter sig selv som yezidier som en særskilt etnisk identitet.

Begrebet diaspora bliver kun brugt af Det yezidiske Forum, når det ser det som sit formål at henvende sig til »diasporaen i Tyskland«. På den anden side taler Den yezidiske Web om »troende af den yezidiske religion i eksil«, og Krikorian bruger udtrykket »minoritet der er bosat i den armenske republik«. På samme måde bliver Tyskland generelt kun nævnt, når der tales om det store hjemsted for yezidier uden for Kurdistan. Kun Det yezidiske forum specificerer, at Tyskland kan tilbyde yezidierne »den historiske chance til frit at udtrykke deres tanker og følelser på skrift og også friheden til at udgive samme«, og anfører som eksempel diaspora, der ikke kun kan forstås som en oplevelse af eksil og tvangsforflyttelse, men også som et potentielt kreativt miljø. Men bortset fra 
det findes der ingen andre referencer til aktuelle (politiske) anliggender i det tyske samfund.

Med undtagelse af Krikorian er alle sites strengt apolitiske og giver derfor ingen referencer (eller links) til den »kurdiske kamp«, ej heller bliver Kurdistan fremstillet som den fremtidige nationalstat for yezidierne. Men interessant nok er de fleste sites enten på engelsk eller tysk (eller på begge sprog) fremfor på kurdisk, tyrkisk eller arabisk, og refererer derved på en indirekte måde til oprindelseslandet for de yezidiske fællesskaber.

Hvis man forsøger at »kortlægge« sammenhængen mellem repræsentationerne af yezidier via de respektive links, viser der sig et billede, der ligner et isoleret øhav snarere end en jævnligt besøgt ø i cyberspace. I dette øhav forekommer Det yezidiske Forum og dets diskussionsforum at være centeret for konktakt - da det modtager de fleste links fra de andre sites - hvorimod alle de andre sites udgør periferien. Det yezidiske Forum tilbyder to links: til »De truede folks samfund $«(G e-$ sellschaft für bedrohte Völker, GfbV) og en tysk jødisk website kaldet »haGalil onLine«. Den yezidiske web præsenterer fire links: til Instituttet for iranske studier på Göttingen Universitet, til Mirza Dinnayis hjemmeside, til diskussionsforummet og til »De truede folks samfund $(\mathrm{GfbV})$. Mirza Dinnayi har kun et enkelt link til sine personlige artikler. Arture Razgoev tilbyder tre links, til en kurdisk-sproget online musik- og boghandel i Sverige, Det yezidiske forum og Det internationale tyrkiske netværk. Endelig har Onnik Krikorian fire links: til Det yezidiske forum, »Groong Armenske Nyhedsnetværk«, »Aragil Nyheder« og Det kurdiske Arbejderparti (PKK). De fleste links går kun den ene vej - kun Göttingen Universitet og Den yezidiske web refererer til hinanden. Således er de fleste sites lokalt orienteret, de koncentrerer sig om lokale begivenheder og nævner stort set ikke yezidiske befolkningsgrupper i andre lande. Derfor synes det tredje parameter for definitionen af diaspora - empati for og solidaritet med fælles-etniske medlemmer bosat $\mathrm{i}$ andre lande indtil videre ikke særlig anvendelig for det yezidiske fællesskab.

Dog ændrer billedet sig en smule, hvis vi vender os mod Diskussionsforummet, som kan være udgangspunktet for, at det yezidiske fællesskab langsomt bliver transnationalt. For nyligt efterspurgte en frivillig, der arbejder med yezidiske flygtninge i Atlanta, gennem Dengê Êzîdiyans elektroniske forum mere information om den yezidiske kultur. Privat kommunikation afslørede, at der bor mindst 30-40 familier i USA og måske 10 familier i Canada. I mellemtiden har han tilbudt at formidle kontakt mellem forfatteren og nogle af de amerikanske yezidier. I august appellerede den samme person til »det store yezidiske fællesskab i den europæiske diaspora« om økonomisk hjælp til yezidier i USA. Hvis en fortsat kommunikation, der involverer yezidier på begge sider af nettet, skal udvikle sig, kunne dette være et af startpunkterne for den yezidiske diaspora til at blive transnational.

Herudover faciliterer den computermedierede kommunikationsteknologi ikke kun spredningen af information blandt yezidier, informationen bliver også præsenteret for et - teoretisk set - vanskeligt afgrænset ikke-yezidisk publikum. Hvis man ser på brugerstatistikkerne, finder man et gennemsnit på 30 besøgende dagligt på Dengê Ếzîdiyans website, der ikke kun kommer fra Tyskland, Tyrkiet, Georgien og Armenien, men fra så langt væk som Australien, Malaysia, Yemen og Japan, for at give bare nogle få eksempler på de ca. 80 lande, der er opført.

\section{Konklusion}

Denne artikel har haft til formål at undersøge brugen af Internettet som en diasporiserings-teknologi blandt yezidiske enkeltindivider og organisationer. Konklusionen er - i lighed med udviklingen $\mathrm{i}$ »den virkelige verden« - at det yezidiske cyperfællesskab er langt fra at være en fuldt færdig diaspora. Alligevel er der identificeret indikatorer, der peger i retning af en diasporisering af yezidierne, fulgt af et skift fra en mundtlig orthopraxy religion til en skriftlig ortodoks religion, hvor forskellige lokale traditioner bliver homogeniseret $\mathrm{i}$ en bindende diasporisk identitet. Migrationsprocessen medfører en ændring af det yezidiske fællesskabs sociale struktur, hvor de religiøse ledere kan miste deres traditionelle privilegerede viden til en gruppe af unge yezidiske intellektuelle og akademikere, der begynder at være determinerende for de fremtidige diskurser for den yezidiske identitet $\mathrm{i}$ diasporaen. Folk, der tager initiativet til kulturelle organisationer, begynder at publicere tidsskrifter eller styrer beskrivelsen og forestillingen af yezidisme på de respektive Internet sites, tilhører for det meste ikke de gejstlige kaster, men er mirîd'er. 
Særligt via Internettet er muligheden for at repræsentere og forestille kollektiv identitet blevet mere udbredt. Teknologien er relativ billig og derfor tilgængelig for en relativ stor kreds af »brugere«, forholdsvis svær at kontrollere og i stand til hurtigt at transportere store mængder af tekst, billeder og lyd rundt i verden. Indenfor World Wide Web er beskrivelsen af kollektiv identitet ikke længere afgrænset til specialiserede intellektuelle, som skriver bøger og artikler i tidsskrifter, eller til de etablerede vogtere af traditioner. Ingen af de »webmasters«, hvis sider er blevet analyseret $\mathrm{i}$ de foregående afsnit, er professionelle specialister i religion, historie eller kultur. De fleste af dem er unge computerspecialister, og andre er ingeniører, folk der i mere traditionelle omgivelser sandsynligvis ville være placeret i den modtagende ende af kommunikationslinjer vedrørende kultur og identitet. De ville være forbrugere af viden og beskrivelser, ikke producenter og uddelere.

Konkluderende må man sige, at mens Internettet udgør en ny form for medie, skaber det ikke nødvendigvis et nyt socialt fænomen. Tværtimod synes det at genskabe sociale relationer udenfor cyperspace, f.eks. som »virtuelle fællesskaber«. I det yezidiske fællesskabs tilfælde - både virtuelt og virkeligt - vil Internettet ikke forårsage en diasporisk bevidsthed, men det kan fremskynde sociale forandringsprocesser, der allerede er i udvikling i det virkelige liv. Cyperspace har kapacitet som et sted, hvor yezidier kan debattere deres kollektive identitet inden for det virtuelle fællesskab og formidle denne repræsentation til andre uden for fællesskabet.

\section{Noter}

Artiklen er baseret på første analyse af materiale fra et igangværende studie med den foreløbige titel »The Meaning of Diaspora: Continuity and Changes of Yezidi Identity in Germany« lavet af en undersøgelsesgruppe, der behandler »Concepts of Meaning as Systems of Orientation« på Institute for Culture Studies i Essen, Tyskland. For mere information om undersøgelsesgruppen henvises til Rüsen (1997). For yderligere teoretiske overvejelser om mulighederne og problemerne omkring etnografi i cyberspace, se Ackermann (2000).

\section{Litteratur}

Ackermann, Andreas, 2000: Das virtuelle Universum der Identität. Überlegungen zu einer Ethnographie des Cyberspace. In: Schomburg-Scherff, Sylvia M./ Heintze, Beatrix (Hg.): Die offenen Grenzen der Ethnologie. Schlaglichter auf ein sich wandelndes Fach. Frankfurt am Main: Verlag Otto Lembeck, 276-290.

Allison, Christine, 1998: From Spoken Word to Written Scripture. The Evolution of Yezidi Religion. In: ISIM Newsletter 1, 14.

Barth, Fredrik (ed.), 1969: Ethnic Groups and Boundaries. The Social Construction of Cultural Difference. London: Allen \& Unwin.

Cohen, Robin, 1997: Global Diasporas: An Introduction. London: UCL Press.

Dengê Êzîdiyan 6/7, 1997. Oldenburg: Dengê Êzîdiyan Verlag.

Dulz, Irene, 2000: Die Religion der Yeziden und ihre heutige Situation in den kurdischen Gebieten des Irak. Magisterarbeit, Universität Hamburg.

Glick Schiller, Nina/Basch, Linda/Blanc-Szanton, Cristina, 1992: Transnationalism: A New Analytic Framework for Understanding Migration. In: Glick Schiller, Nina/Basch, Linda/Blanc-Szanton, Cristina (eds.): Towards a Transnational Perspective on Migration. Race, Class, Ethnicity, and Nationalism Reconsidered (Annals of the New York Academy of Sciences, Vol. 645). New York: The New York Academy of Science, 1-24.

Kreyenbroek, Philip G., 1995: Yezidism - Its Background, Observances and Textual Traditions. (Texts and Studies in Religion, Vol. 62). Lewiston/Queenston/ Lampeter: Edwin Mellen Press.

Kulturforum der yezidischen Glaubensgemeinschaft e.V. (Hg.), 2000: Menschenrechts-Situation und Asylproblematik der Yeziden. Oldenburg.

Müller, Klaus E., 1987: Das magische Universum der Identität. Elementarformen sozialen Verhaltens - Ein ethnologischer Grundriß. Frankfurt am Main/New York: Campus.

Rüsen, Jörn, 1997: Sinnkonzepte als lebens- und handlungsleitende Orientierungssysteme. In: Jahrbuch 1996 des Kulturwissenschaftlichen Institutes. Essen, 213-219.

Safran, William, 1991: Diasporas in Modern Societies: Myths of Homeland and Return. In: Diaspora 1, 83-99.

Spuler-Stegemann, Ursula, 1997: Der Engel Pfau. Zum Selbstverständnis der Yezidi. In: ZfR-Zeitschrift für Religionswissenschaft 5, 3-17. 


\section{Links}

Dengê Êzîdiyan - Forum of Yezidism http://www.yezidi.org

Dengê Êzîdiyan International Discussion Forum http://www.yezidi.org/messageboard/ wwwboard.html

Dengê Êzîdiyan User Statistics (in Dutch) http://nl.viewstat.nedstatbasic.net/cgi-bin viewstat?name=yezidi

Êzidiyan Student Community (ÊSG) http://www.ezidenweb.de

Dinnayi, Mirza, Homepage of http://www.uni-jena.de/ i8almi/

Krikorian, Onnik: The Yezidi Kurds in Armenia http://www.freespeech.org/oneworld/yezidi/ yezidi.htm
Nezir Bulut

http://members.tripod.de/NezirBulut/galaxi2/ index.html

Questionnaire concerning health aspects of Yezidi life in Germany (in German)

http://www.uni-jena.de/ i8almi/bogen.html

Razgoev, Arture Felix, homepage of

http://www.geocities.com/Baja/Outback/4147/ Yezidis.html

Yezidi Web http://www.Yezidi.net/

Alle links er sidst blevet checket den 24. august 2000.

Andreas Ackermann er kulturforsker ved det kulturvidenskabelige institut i Essen, Tyskland 